\title{
Ethno-medicinal Uses of Some Shell Fishes by People of Kosi River Basin of North-Bihar, India
}

\author{
Amit Kumar Prabhakar and S. P. Roy \\ University Department of Zoology, T. M. Bhagalpur University, \\ Bhagalpur 812 007, Bihar, India
}

KEYWORDS Ethno-medicines. Shell Fishes. Aboriginal People. Kosi River Basin. North-Bihar

\begin{abstract}
During present investigation medicinal uses of these shell fishes has been studied. It was found that after removal of shell and mantle of Pila, Bellamya, Lamellidens and Parreysia, the flesh of these molluscs in various forms consumed for the cure of some aliments of local people and also provide essential animal proteins, steroids, vitamins and minerals to the people of the region. The flesh of Pila and Viviparous sp. is used as medicine to cure asthma, swelling of joints, burns by aboriginal people of this region. The foot portion of these edible shell fishes is eaten in the form of curry as well as in roasted form at regular intervals. The soup of eggs of these species are also used as medicine and given to children suffering from rickets. The flesh of Lamellidens, is eaten in the form of cooked curry and given to people suffering from cardiac diseases and blood pressure. It was also observed that the local people of the region consumed these shell fishes to cure a number of other ailments such as rheumatism, calcium metabolism, heart diseases, conjunctivitis, giddiness, nervousness, dehydration and various gastro intestinal disorders.
\end{abstract}

\section{INTRODUCTION}

Shell fishes are economically important animal biodiversity interacting intimately with local indigenous people of the rural sector of the region, Of these animal biodiversity the species belonging to Paratelphusa, Macrobrachium, Bellamya, Pila, Achatina, Lamellidens, Novaculina and Parreysia are edible to aboriginal people and particularly they have been used as medicines for the cure of a number of ailments such as rheumatism, cardiac diseases, controlling blood pressure, asthma, rickets, calcium metabolism, nervousness, giddiness and also providing missing vitamins and minerals (Mahata 2002). The shell fishes and crustaceans are farmed commercially and dominate world output of aquacultural resources. Among shell fishes, the pearl Oyster, Unio, Pila, blue mussels at 3.4 million tonnes (including shell) dominates in one hand and crustaceans crabs (Paratelphusa spinigera) and prawns (Macrobrachium sp.) on other hand. Fish farming is a solution to the world food problem source of low cost animal proteins for lower income populations. The forces that have made aquaculture the world's fastest growing source of animal protein over the last decade are likely to make it the fasted growing resource during this decades well.

Considerable information has been available on the taxo-eco-biology of shell fishes of Indian sub-continent (Tonapi 1971; Subba Rao and Mitra 1982; Sharma et al., 1983; Singh 1990; Roy 2003;
Roy and Singh 2007). All these works mainly concerned with the taxonomy, biology, life cycle, ecology and behaviour of shell fishes. Practically no information is available on the shell fisheries potential of the Kosi river basin and the uses of shell fishes as medicines to cure various ailments of the local people. Therefore, the objectives of present study is to provide information on the ethno-medicinal uses of shell fishes for the cure of a number of prevailing diseases in this wetland dominated region of North-Bihar.

\section{MATERIALS AND METHODS}

Kosi basin of North-Bihar comprising districts of Khagaria, Supaul, Saharsa, Madhepura and Purnea were selected for the present study. Shell fishes exploited by different categories of people in these five districts were collected.

Extensive field trips were conducted regularly and data were collected after survey, interviews and on spot enquiries. The shell fishes were collected and preserved in 3\% formalein and brought to the laboratory. The intact animals were washed thoroughly in running tap water and slightly decalcified in aqueous acidic medium to find out growth rings. The specimens were identified with the help of available literature (Sharma et al. 1983; Subba Rao et al. 1986). The collected specimens were submitted in the museum of University Department of Zoology, T. M. Bhagalpur University. 
The uses of these shell fishes as food, medicines, vitamin supplements etc. were investigated after random sampling of different families, villages and block level people of the area.

\section{RESULTS AND DISCUSSION}

The present study on the status of shell fisheries and their ethno-medicinal uses by the inhabitants of the area of North-Bihar reveals that the river basin of this region is rich in diversity of molluscan and crustacean fauna. The diversity, abundance and dominance of shell fishes indicate well established balanced ecosystem for supporting a complex food web exists in this basin. The abundance of shell fishes in terms of species diversity indicate a good life support system for fishes and birds. Shell fishes are the major component of the macro-invertebrates, they form link between zooplankton and vertebrate taxa, such as fishes and birds and play a key role in the energy flow and bio-geochemical cycle of the wetland habitats. A number of fish and avian fauna diversity directly depend upon the molluscs population of these habitats. The commercial aspect of shell fishes as raw material for food, finance, recreation, medicines, vitamins and minerals supplements etc., for local human population and ecological aspect for increasing biological diversity and maintaining ecological balance for the animals occupying the higher trophic level of the food chain. Thus, the considerable scope with respect to the shell fisheries for their medicinal value and these resources need judicious utilization on commercial basis to generate employment opportunity and enhance the income of the local people (Rao 1969).

\section{Nutritional and Medicinal Uses of Some Edible Gastropoda, Pelecypoda and Crustacea}

The foot of Pila sp; Bellamya sp; Lamellidens sp; and Parreysia sp is large, muscular, rich in proteins, vitamins ( A, B, D) and minerals but is fat free. It is used as main nutritional element in the form of soup, curry as well as roasted by aboriginal and their allied of Kosi region of NorthBihar. The visceral mass is also used as food in curry form after elimination of gastrointestinal tract in one hand and on other hand the muscular parts such as hepato- pancreas of Paratelphusa sp. and entire muscular pars of Macrobrachium

\begin{tabular}{|c|c|c|c|}
\hline $\begin{array}{l}\text { S. } \\
\text { No. }\end{array}$ & Diseases & $\begin{array}{l}\text { Species used to } \\
\text { cure diseases }\end{array}$ & Method of application for cure of diseases \\
\hline 1 & Asthma & Bellamya Sp. & $\begin{array}{l}\text { Soup prepared from the foot of Bellamya sp is } \\
\text { used to cure these diseases. }\end{array}$ \\
\hline 2 & Arthritis & & -do- \\
\hline 3 & Joint pain and & & -do- \\
\hline 4 & Rheumatism & & -do- \\
\hline 5 & Conjunctivitis & Bellamya bengalensis & $\begin{array}{l}\text { To get cured from conjunctivitis, Bellamya } \\
\text { bengalensis are collected from pond and are } \\
\text { kept in clean fresh water in a earthen pot for } \\
\text { night and the water is used like eye drop. This } \\
\text { method is considered best for the cure of this } \\
\text { disease in this region. }\end{array}$ \\
\hline 6 & Rickets & Pila $\mathrm{Sp}$ & $\begin{array}{l}\text { Soup prepared from the eggs of Pila is used to } \\
\text { cure rickets in children. }\end{array}$ \\
\hline 7 & Cardiac ailments & Lamellidens Sp. & $\begin{array}{l}\text { Soup prepared from the foot of Lamellidens } \\
\text { Sp. and Parreysia sp. is used to cure the cardiac } \\
\text { ailments and to control blood pressure. }\end{array}$ \\
\hline 8 & Blood pressure & Parreysia $\mathrm{Sp}$. & -do- \\
\hline 9 & $\begin{array}{l}\text { Giddiness and } \\
\text { dehydration }\end{array}$ & Lamellidens Sp. & $\begin{array}{l}\text { The shell powder of Lamellidens sp. mixing } \\
\text { with honey is used for the remedy of giddiness } \\
\text { and dehydration. }\end{array}$ \\
\hline 10 & Nervousness & Lamellidens Sp. & -do- \\
\hline 11 & Night blindness & $\begin{array}{l}\text { Bellamya Sp. } \\
\text { Pila Sp. }\end{array}$ & $\begin{array}{l}\text { Curry of the foot of Bellamya sp is eaten regu- } \\
\text { larly by aboriginal people of Kosi region to } \\
\text { cure night blindness and for better eye sight. }\end{array}$ \\
\hline 12 & Anaemia & $\begin{array}{l}\text { Paratelphua } \mathrm{Sp} . \\
\text { Macrobra chium } \mathrm{Sp} .\end{array}$ & $\begin{array}{l}\text { Soup and curry prepared from these shell fishes } \\
\text { helpful in the cure of anaemia and vitamin } \\
\text { deficiencies; cure paralysis, promote strength; } \\
\text { cure arthritis. }\end{array}$ \\
\hline
\end{tabular}


sp. are also rich in proteins, vitamins and minerals but is not fat free because these animals contain enourmous amount of fat body which are used as food. Thus, Paratelphusa and Macrobrachium are calorigenic and these provide energyrich food to the local people.

Negi and Palyal (2007) studied the traditional used of animal and animal products in medicine and rituals by the Sloka tribes of district Pithoragharh, Uttaranchal (India). They observed that the meat of Paratelphusa is believed to a promoter of strength, corpulence and is a good remedy for the diseases of the blood. Roy and Singh (2007) have investigated the ethno-medicinal uses of animal diversity by the tribal people of Santhal Pargana (Jharkhand: India) and found that termites, earthworms, Pila Unio, frog, snakes, rat, pigeon, are taken as food for the cure of rheumatism, asthma, anaemia, promote digestion, muscle dystrophy, promote lactation, cure tuberculosis, cure paralysis, regulate menstrual disorder etc. The local treatment procedures using indigenous method to cure a number of diseases is called horopathy in the region. In the similar manner in the region of North-Bihar, which is wetland dominated the use of shell fishes in the treatment of a number of diseases on one hand and daily food item on the other hand are common practice. Therefore, the conservation and management of these shell fishes are necessary for the sustenance of local people.

The uses of shell fishes as ethno-medicines in Kosi basin is a traditional medical practice. Ethno-medicinal studies are health care practices,
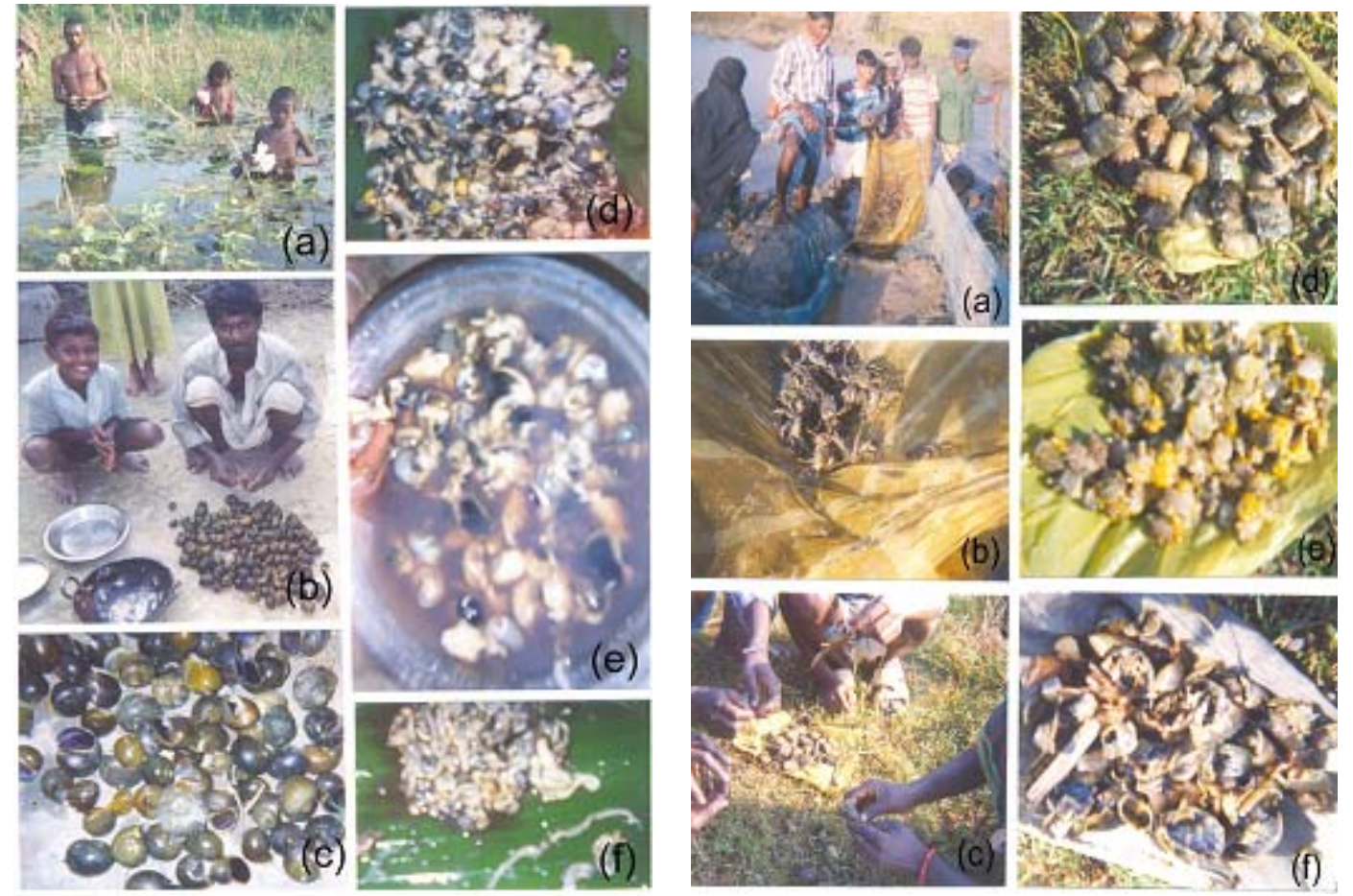

Fig. 2. (a) Fishermen capturing paratelphusa. sp and Macrobrachium sp.; (b) a higher magnification of fig. (a) captured Paratelphusa sp.; (c) Breaking of legs of Paratelphusa sp. by the local inhabitants; (d) Paratelphusa sp. without legs; (e) Nutritional and Medicinal parts of Paratelphusa sp.; (f) Shell of Paratelphusa sp. used in medicinal purpose.

Nutritional and Medicinal parts of Pila sp. and Bellamya sp.; (e) Liquid of Pila sp. \& Bellamya sp. having nutritional value; (f) Non-feeding parts of Pila sp. \& Bellamya sp. 
the prevalence of illness and the distribution of knowledge about illness attributes. Of all the shell fishes studied Pila and Lamellidens are exploited by the local people for the cure of rickets in children, control of blood pressure and cure of cardiac diseases (Figs. 1 and 2), cure of night blindness.

Paratelphusa and Macrobrachium are generally used to compensate the nutritional deficiency, minerals and steroids requirement. These shell fishes are consumed by high income populations and are used to cure anaemia and to over come vitamin deficiency.

There is acute pressure on these shell fishes in the Kosi river basin as local human population exploit them recklessly. Consequently there is declining trend in the propagation of these shell fishes in the region. The conservation and management of these shell fishes are needed for the maintenance of good health and free from diseases among local people of the region.

The general ecological conditions prevailing in Kosi basin of North-Bihar is congenial for the propagation and sustenance of shell fisheries in the region. The general limnological conditions viz. $\mathrm{pH}$ always in alkaline range, normoxic water, absence of $\mathrm{FCO}_{2}$ presence of $\mathrm{CO}_{3}{ }^{-}$alkalinity, silicate is appreciably in low quantities, $\mathrm{PO}_{4}^{-}$is in very meagre amount, $\mathrm{NO}_{3}$ is in moderate amount and total hardness in less amount of the Kosi river basin indicate good physico-chemical condition for the propagation growth and maintenance of shell fishes. The local inhabitants directly depend on these shell fishes for food and also to supplement multinomial deficiency. In this rural region the shell fisheries is the only solution for the protein-rich food demand of the local people as both high cost and low cost proteins for both high income and low income populations may get through these. Shell fishes grow in combination with paddy, Makhana (Furyale ferox) Shinghara (Trapa bispinosa) and other aquacultural programmers offer a highly efficient way of expanding animal protein supporting in a protein hungry world.

It was observed that Unio, Pila and Parreysia (including shell) dominates in food in one hand and in crustacens Crabs (Paratelphusa spinigera) and prawn (Macrobrachium sp.) on the other hand. Shell fisheries is a solution to the world food problem because it is easily available source of low cost animal protein for lower income populations. The shell of Pila sp. Unio sp. Parreysia sp. are used as lime, button, healing wounds and their been used could also for magico-religious purposes.

\section{REFERENCES}

Mahata MC 2002. Edible Shell Fish (Molluscs) of Chotanagpur Plateau, Jharkhand (India). Baripada, Orissa: Bio-publications, pp. 1-133.

Negi CS, Palyal VS 2007. Traditional uses of animal and animal products in medicine and rituals by the Shoka tribes of district Pithoragarh Uttaranchal, India. Ethno-Med, 1(1): 47-54.

Rao K: 1969. Mollusca have many uses. Indian Farming, 29(9): 41-45 and 62 .

Roy SP 2003. Secondary productivity of fresh water ecosystem. In: JS Datta Munshi, J Ojha, TKGhosh (Eds.): Advances in Fish Research. Delhi: Narendra Publishing House, Volume 3: pp. 99-108.

Roy SP, Singh BK 2007. Ethno-medicinal uses of animal diversity by tribal people of Santhal Pargana in Jharkhand, India, In: AP Das, AK Pandey (Eds.): Advances in Ethno-botany. Dehra Dun: Bishen Singh Mahendra Pal Singh, pp. 211-217.

Sharma UP, Roy SP, Rai DN 1983. Aquatic Molluscs of Bhagalpur. J Biol Bull India, 5(2): 147-155.

Singh 1990. Density, biomass and secondary productivity of the Prosbranchs Pila globosa and Bellamya bengaleusis in a feeder Tank, Jamalpur. J Freshwater Biol, 2(2): 251-256.

Subba Rao NV, Mitra SC 1982. Bioecology of two Malaniid Snails (Mollusca: Gastropoda) in a pond near Calcutta. Bull Zool Surv India, 34(1 and 2): 21-34.

Tonapi GT 1971. Studies on the freshwater and amphibious Mollusca of Poona with notes on their distribution. Part II. J Bom Nat Hist Soc, 68: 115-176. 